\title{
Til menneskehedens bedste
}

\section{Henrik Døcker}

\section{FN's menneskerettighedserklæring og FN's folke- drabskonvention fyldte begge 60 år i 2008. Samtidig fejrede Den Europæiske Menneskeret- tighedsdomstol 50-års jubilæum. Har de hjulpet?}

Rigtig mange diktatorer og utvivlsomme 'storkrænkere' af menneskerettighederne har fundet en naturlig død: Stalin, Pol Pot, Kim il Sung, Mao Zedung, Idi Amin - for blot at nævne nogle af de mest notable. Først over 50 år efter afslutningen af Anden Verdenskrig er verden nogenlunde enedes om at der må sættes en effektiv stopper for det. FN's verdenserklæring om menneskerettighederne og FN's konvention mod folkedrab af hhv. 10. og 9 . december 1948 var imidlertid de historisk vigtige startskud til en udvikling, som i det 21. århundrede er kommet virkelig i omdrejninger.

Samtidig kunne Den Europæiske Menneskerettighedsdomstol i Strasbourg i efteråret 2008 fejre 50-året for igangsættelsen af sin virksomhed, otte år efter vedtagelsen af den europæiske menneskerettighedskonvention 4. november 1950.

Det komplicerede fletværk af defi- nition af de enkelte menneskerettigheder (der er ca. 30 af dem), tilvejebringelse af en domstol, der internationalt skal udmåle godtgørelser for overtrædelser af dem, samt det brede ønske om at straffe de ansvarlige for de helt grove, omfattende krænkelser har kun under særlige omstændigheder og overvejende i Europa udmøntet sig i målelige resultater.

Der skal her gøres et forsøg på at skille uendelige mængder af idealisme fra et betydelig mindre opbud af realiteter. Det er væsentligt at forstå, at historien om den internationale menneskeretsbeskyttelse i det væsentlige drejer sig om et politisk magtspil, hvor kun europæiske ofre for menneskeretskrænkelser i de 50 år har fået nogen som helst form for godtgørelse for krænkelserne.

Det følgende vil i det væsentlige give en oversigt over, hvad man in- 
tereuropæisk har gjort for at rette op på menneskeretskrænkelser og alvorlige folkeretsbrud.

FN's menneskerettighedskommission, dannet umiddelbart efter FN's oprettelse i 1945, barslede på kun tre år med den nævnte verdenserklæring, men den forpligtede ikke nogen. Den indkredsede - med stærk inspiration af den franske erklæring om menneskets og borgerens rettigheder af 1789 - hvad det var, som skulle beskyttes.

Den personlige frihed (fravær af vilkårlige fængslinger), forbud mod tortur, ytrings-, forenings-, forsamlings-, religionsfrihed, stemme- og valgret, ejendomsrettens ukrænkelighed osv., osv. Faktisk en hel masse rettigheder, danskerne kendte fra deres grundlov af 1849 .

100 år havde gjort formuleringerne lidt 'støvede', det rådedes der nu bod på, men først og fremmest skabtes som noget nyt internationale organer, som kunne korrigere staternes egne 'godkendelser' af indtrufne menneskeretskrænkelser.

Det er nemlig således, at man i almindelighed ikke kan tale om en menneskeretskrænkelse, med mindre der har været en offentlig (dvs. statslig) aktør ind i billedet. Hele beskyttelsessystemet er opbygget som borgerens værn mod staten $\mathrm{i}$ situationer, hvor denne har forløbet sig, om man så må sige. Eksempler i det efterfølgende vil vise, at krænkelserne imidlertid godt i deres udgangspunkt kan være forvoldt af pri- vate. Det er så det efterfølgende statslige ansvar, der har svigtet.

\section{Én mands værk}

Mens ingen enkeltperson kan tage æren for FN-verdenserklæringen, skyldtes formuleringen af folkedrabskonventionen i det væsentligste den landflygtige polske jurist Raphael Lemkin.

Han var under krigen flygtet fra sit fædreland og var via Sverige kommet til USA, hvor han - som tilmed var jøde - fik støtte til en konvention mod hvad han kaldte folkedrab, dette at mennesker på grund af deres nationalitet, race, etniske tilhørsforhold eller religion alene blev genstand for forfølgelse med henblik på hel eller delvis udryddelse af den gruppe, han/hun tilhørte.

Denne konvention blev altså til i samme periode som menneskeretserklæringen, men den tilsigtede $\mathrm{i}$ modsætning til erklæringen at forpligte staterne til at retsforfølge de ansvarlige. Nazitysklands målrettede udryddelse af Europas jøder var hans stærkeste inspiration, men også Det Osmanniske Riges tilsvarende deportationer af og drab på dette riges armeniere i 1915 var en tilskyndelse.

Mens folkedrabskonventionen imidlertid ikke fik nogen betydning før i 1990'erne, igangsatte ikke mindst Strasbourg-domstolen en vældig udvikling, koncentreret om 


\section{HENRIK DØCKER}

at godtgøre menneskeretsofrene.

Efter at denne domstol (og tidligere supplerende Europarådets Ministerkomité) nu i alt har afgjort ca. 12.500 sager endeligt - og et større antal sager er blevet forligt kan man spørge, hvilke rettigheder der så særligt er blevet styrket? $\mathrm{Og}$ hvilke rettigheder krænkes fortsat $\mathrm{i}$ beklageligt omfang?

Noget kort og koncist svar kan af mange grunde ikke gives, men der kan peges på både positive og negative tendenser. Først må det lige med, at det i perioden indtil lidt ind i 1990'erne alene var Vesteuropa, som havde ratificeret menneskerettighedskonventionen og underkastede sig Menneskerettighedsdomstolens afgørelser. I dag er hele Europa (undtagen Hviderusland), i alt 47 lande, med. De fleste af krænkelserne har ikke nogen udtalt politisk karakter, men vedrører borgerlige rettigheder og vil i reglen ikke være begået forsætligt.

\section{Flest krænkelser i Italien}

Lad os begynde med Danmark og se på det positive. Danmark har kun tabt en god håndfuld, dvs. under ti, sager i Strasbourg, og har hurtigt ændret den lovgivning, der i de givne tilfælde gav anledning til menneskeretskrænkelsen. Efter at det i Hauschildt-sagen i 1989 blev fastslået, at den samme dommer ikke både kunne forlænge fængslingskendelser under en verserende straffesag og afsige dom i sagen, ændredes denne praksis hurtigt. Ligeledes har afgørelser om udvisninger af straffede udlændinge, hensynet til journalisters dækning af i øvrigt strafbare handlinger, gennemførelse af retssager inden for rimelig tid og frafald af krav om fagforeningstilhørsforhold været direkte dikteret af domme, hvor Danmark fandtes at have krænket konventionen (Amrollah-, grønjakke-, bløder-, og Sørensen/Rasmussen-sagerne).

I praktisk taget alle de domme, hvor et land har krænket konventionen, er landet blevet pålagt at betale den krænkede borger en godtgørelse, som så er blevet erlagt. Netop bestemmelsen om at en sag skal afgøres inden for rimelig tid, er særlig hyppigt blevet overtrådt, ja det er den enkelte bestemmelse, som der er faldet flest domme om - og det er her Italien, der er rekordholder!

Til dato er der i Strasbourg endeligt afgjort omkring 6000 sager om det uvæsen, at retssager trækker urimeligt ud, dvs. i visse tilfælde i årtier! Med inspiration bl.a. fra Spanien har Strasbourg-domstolen da ivret for, at de enkelte lande indførte nationale klageorganer til at behandle langstrakte sager.

Italien fulgte dette op gennem den såkaldte Pinto-lov, men desværre har det i en hel del tilfælde vist sig, at de godtgørelser, italienske domstole nu tilmåler borgerne for forsinkelser, er alt for lave - i 2004 fik en række italienske klagere så- 
ledes ved Strasbourg-domstolens mellemkomst forhøjet deres godtgørelser med ca. fem gange i forhold til de beløb, italienske domstole havde tilkendt dem. I 2007 var der eksempelvis stadig 25 Strasbourg-domme mod Italien om langsommeligheden ved domstolene (men fx endnu flere vedrørende Grækenland, Tyrkiet og Polen). Andre central- og østeuropæiske lande har arbejdet energisk på at overholde en rimelig ekspeditionstid.

\section{Tortur i Tyrkiet}

Tortur samt umenneskelig eller nedværdigende behandling er næst efter henrettelse den alvorligste menneskeretskrænkelse, man kan forestille sig. Kun Tyrkiet er i stor skala blevet dømt for dette i Strasbourg, til dato i over 150 tilfælde, mens det i omkring 100 tilfælde er dømt for drab ved nedskydning, typisk under aktioner mod kurderne. Det er vanskeligt at se nogen tydelig nedgang i disse typer sager.

Dette land er siden sin første dom i Strasbourg i 1995 blevet dømt for krænkelse af konventionen i 1395 tilfælde og overgås totalt kun af Italien. Det har for tiden 9000 verserende sager, men det er ingenting mod Ruslands over 20.000 af slagsen. Mange domme har vedrørt Tjetjenien, men russiske bortførelser af og drab på unge tjetjenere er ikke ophørt.

Generelt kan imidlertid konstate- res, at tortur i hele Europa efter at Jerntæppet gik op i 1990/91, anvendes langt mindre. Såvel bortfaldet af de kommunistiske, som tidligere af de spanske, portugisiske og græske diktaturstater har fjernet disse uhyrligheder.

Mens Tyrkiet altid har betalt godtgørelser til torturofre eller efterladte til henrettede personer efter dom i Strasbourg, ligger det tungt med straf over gerningsmændene, noget som under alle omstændigheder helt påhviler enkeltstaterne uden international medvirken. Selv om der har været tusinder af sager mod tyrkiske politifolk og officerer, er kun et fåtal dømt, og i næsten alle tilfælde er deres straffe højest blevet betingede.

Europarådets Ministerkomité følger gennem et særlig sekretariat i Strasbourg nøje Menneskerettighedsdomstolens afgørelser op og bombarderer sendrægtige stater med påmindelser om at ændre love eller former for retspraksis, som er blevet underkendt.

I spredt fægtning kan det nævnes, at Østrig måtte ændre sin retsplejelov, fordi sigtede sad for længe i forundersøgelsesarrest, Belgien sin straffelov, hvorved administrativ frihedsberøvelse afskaffedes, foruden sin civilret, således at børn født uden for ægteskab blev ligestillet med ægtefødte børn, Holland sin militære straffelov, således at soldater fik bedre retsgarantier, Schweiz sin ægteskabslov, således at 


\section{HENRIK DØCKER}

fraskilte ikke var i en tidsmæssig 'karantæne' inden de kunne gifte sig igen, Storbritannien sine regler for transseksuelle og Portugal hele sit domstolssystem.

Særlig interesse har knyttet sig til en stribe sager fra de tidligere kommunistiske diktaturstater i Centraleuropa. Det har vist sig, at Strasbourg-domstolen i en del tilfælde har kunnet hjælpe personer i Tjekkiet, Rumænien, Ungarn m.fl. stater, som søgte retfærdighed som følge af uret, der blev begået mod dem forud for de pågældende staters ratifikation af menneskerettighedskonventionen i 1990'erne.

Det har ikke mindst drejet sig om ret til ejendom, som var nationaliseret under kommunismen. Andre sager har drejet sig om ophævelse af rigoristiske indgreb over for folk, der tidligere var ansat i et lands sikkerhedstjeneste eller afhjælpning af statsløshed som følge af de nye grænser i Østeuropa.

\section{Politiske massemyrderier}

Folkedrabskonventionen fik som nævnt først rigtig betydning, da der som følge af folkedrabene i Eksjugoslavien og Rwanda i 1990'erne blev nedsat særlige tribunaler til at pådømme personer med ansvar for bl.a. denne forbrydelse - som sammen med krigsforbrydelser og forbrydelser mod menneskeheden regnes for særlig grove brud på folkeretten. Disse alvorlige krænkelser omfatter altså forbrydelser i stor skala og over en vis periode. Sager af denne karakter kan siden oprettelsen af Den Internationale Straffedomstol i 2002 indbringes for denne domstol, hvis en stat ikke vil eller kan retsforfølge personer, sigtet for sådanne forbrydelser begået på dens territorium.

Det har dog vist sig overordentlig svært at bevise folkedrab i talrige tilfælde, hvorfor kun ganske få personer hidtil er blevet dømt netop for det - den første var den rwandiske borgmester Jean-Paul Akayesu, der i 1999 idømtes livsvarigt fængsel for opfordring til og deltagelse i folkedrabet på Rwandas tutsi-befolkning i 1994.

En række andre tiltalte er så i stedet blevet dømt for forbrydelser mod menneskeheden - det omfatter bl.a. drab, slaveri, deportation, tortur, voldtægt, dvs. i virkeligheden den samme slags ugerninger, blot uden den forsætlige udryddelseshensigt vedføjet.

Kun nogle af de politiske massemyrderier, der er begået i de sidste ca. 100 år, kan med alle eksperters tilsagn regnes for folkedrab, og disse er i alle tilfælde begået i krigstid: Europas jøder, Eksjugoslaviens bosniakker, Rwandas tutsier.

En stribe andre vækker heftig diskussion, selv om folkedrabsmotivet i vide kredse kaldes indiskutabelt: Det Osmanniske Riges armeniere (1915), Sovjetunionens ukrainske befolkning (1932-33), 
Guatemalas indianere (1982), Cambodias befolkning (1975-79). Folkedrab kan ifølge konventionen også forekomme i fredstid. Retsopgør efter kommende folkedrab vil kunne tænkes indbragt for Den Internationale Straffedomstol.

Kun Europas fællesindsats for menneskerettighedsbeskyttelse er omtalt i det foregående, eftersom de øvrige verdensdele ikke har systemer, der effektivt sætter ind over for krænkelser.

Men FN's to menneskerettighedskonventioner for hhv. borgerlige/ politiske og økonomiske/sociale/ kulturelle rettigheder af 1966, der gjorde 1948-erklæringen forpligtende, har haft stor politisk betydning og har inspireret en række landes forfatninger. Disse to har tillige med en række specialkonventioner (mod fx diskrimination) også fået kontrolorganer (komiteer), som imidlertid kun kan give henstillinger til staterne og ikke træffe beslutning om godtgørelser.
Som sådan har menneskeretsbegrebet altså været murbrækker for mange forbedringer i menneskers tilstand, uanset enorme forskelle i den nærmere definition af dem i verdens 196 lande. Folkedrabskonventionen har næppe virket præventiv på nogen måde, men dens definition af et uhyggeligt begreb har været vigtigt og befordrende for kodificeringen af den internationale strafferet, som er skudt op inden for den sidste halve snes år.

Den strafferet, som bl.a. gjorde det muligt at bringe to diktatorer den nu afdøde serber Slobodan Milosevic og liberianeren John Taylor - til en anklagebænk i Haag.

Henrik Døcker er journalist og forfatter. Han har i dette nummer af Udenrigs også anmeldt "Blood and Soil - A World History of Genocide and Extermination from Sparta to Darfur". 


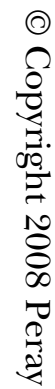

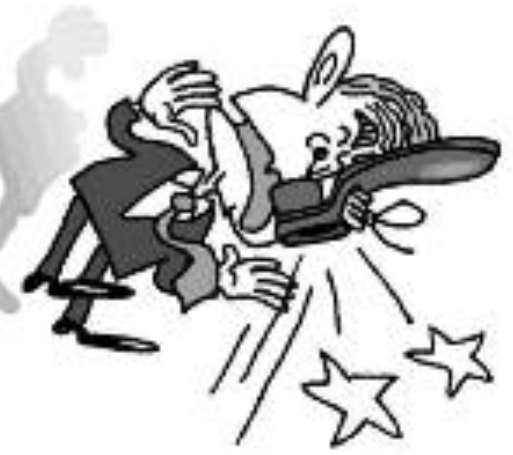

告

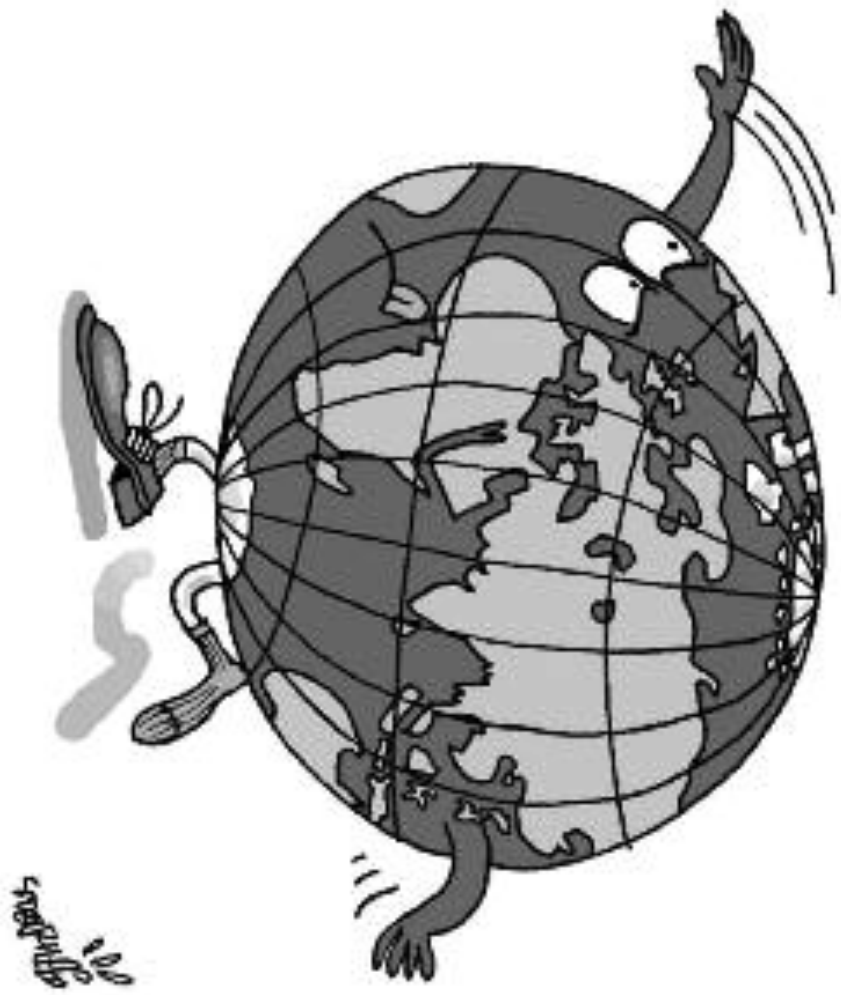

